\title{
ANALYSIS OF SELECTED HAND ANTHROPOMETRIC MEASUREMENTS AMONG SOUTH WEST ZONE INTER UNIVERSITY MALE HANDBALL PLAYERS
}

\author{
C. Jayakumar ${ }^{\mathrm{a}}$, S. Rameshkanan ${ }^{\mathrm{a}}$ and B. Chittibabu, ${ }^{\mathrm{b}, *}$ \\ ${ }^{a}$ Ph.D. Research Scholar, Department Physical Education and Sports Sciences, Annamalai \\ University, Annamalainagar - 608 002.Tamil Nadu, India \\ ${ }^{b}$ Assistant Professor Department Physical Education and Sports Sciences, Annamalai \\ University, Annamalainagar - 608 002.Tamil Nadu, India \\ *Corresponding Author Ph: 09443531508;Email: b.chitti@ hotmail.com
}

DOI: 10.26524/1343

\begin{abstract}
The purpose of this study was to analyse the selected hand anthropometric measurements among south zone inter university male handball players. The selected players right and left hand length and width were measured on 144 male handball players who had right hand as dominant hand. These players took part in south west zone inter university handball tournament for the year 2010-2011 organized by S.R.T.M University, Nanded, Maharashtra. In this study date was collected from teams who reached quarter finals and Annamalai University team. The hand length and width was selected as criterion variable and measured by vernier caliper, gulick tape and measuring scale. The collected data was analysed using ANOVA, when $F$ is found to be significant Tukey HSD post hoc test was applied. The result of the study showed that right hand length $(F=1.61, p=$ $0.126)$ and left hand length $(F=1.19, p=0.308)$ show no significant difference between the groups. However, right hand width $(F=5.450, p=0.000)$ and left hand width $(F=6.302, p=0.000)$. It shows that Rajasthan university handball players showed greater hand width on both hands than other team players. It can be concluded that hand width shows significant variations among the south west zone inter university handball tournament. The criterion variables which are selected in the present study show significant impact on griping the ball.
\end{abstract}

Keywords: Grip strength, hand length, hand width, handball, players

\section{Introduction}

Handball is a fast body contact team game. Handball players require greater grip strength to hold the ball which prevents fumble and fall. In order avoid fumble and fall they require better hand anthropometric measurements. Human beings possess different hand anthropometric dimensions either narrow or broad which are distributed in the normal population, with slight male/female differences in the median and range values. One such dimension with these gender differences is hand shape. Hand shape has been defined in various ways, but often as simply the hand width/hand length ratio (W/L ratio). Thus hands with varying W/L ratios can be described as ,long and narrowee, ,average lookingee, or ,relatively square ${ }^{\text {ee }}$ by how long the hand is in relation to the width of the palm [1].

Numerous hand-grip strength studies with healthy adults have shown that anthropometric variables, such as height, weight, hand length, and hand width, are positively associated with grip strength, as are other anatomical variations, such as the presence of a flexor digitorum superficialis tendon in the little finger. Paediatric studies have shown that the anthropometric variables of body mass index, height, weight, hand length, palm length and palm width are highly correlated with grip strength in children [1]. Though literature related to anthropometric characteristics of handball players are available, information in India context is scanty in this regard. To fulfill the lacunae of literature, the present study was planned. The purpose of this study was to analyse the selected hand anthropometric measurements among south zone inter university male handball players.

\section{METHODS}

\section{Subjects and Variable}

In this study the selected one hundred and forty four (144) male handball players, selected from south west inter university, handball tournament for the year 2010-2011, organized by S.R.T.M. University, Nanded, Maharashtra. In this study data was collected from teams who reached quarter finals and Annamalai University team. These selected subjects, who practice handball regularly and take part in competition. The mean \pm SD of age, height, weight and BMI were $21.42 \pm 1.82$ year, $1.76 \pm$

$0.74 \mathrm{~m}, 66.0 \pm 9.26 \mathrm{~kg}$ and $21.58 \pm 2.27$ respectively on average, the players had $5.9 \pm 2.1$ year of playing experience and represented various format of competition. The variable selected in this study was right and left hand length and width which were measured by vernier caliper, gulick tape and measuring scale. Statistical techniques

The selected hand grip strength was statistically examined by applying analysis of variance (ANOVA). When $F$ ratio was found significant, Tukey HSD post hoc test was applied. This statistical work was done with help of SPSS 11.5 version and out puts reproduced as it is. 


\section{Result}

The mean value and standard deviation on right and left hand length of various handball teams who reached quarter final in south west zone inter university handball tournament for the year 2010-2011 are presented in figure 1.

Figure 1

Graph shows hand length of various handball teams

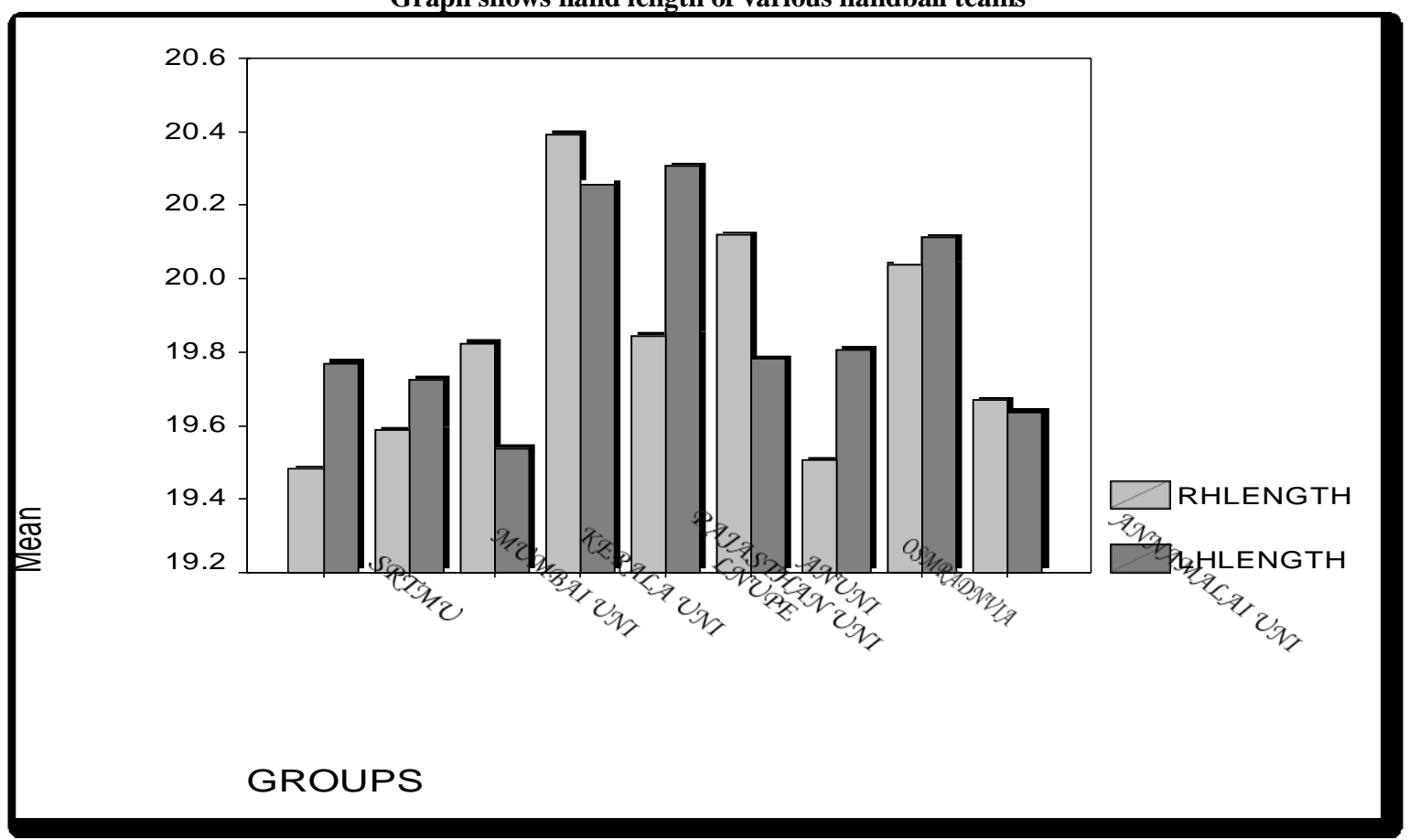

It is clear from Table 1 that the obtained $F$ ratio 1.614 and $1.192(p>.126$ and .308$)$ respectively is less than the table value of 2.51 required at 8 and 144 degree of freedom for 0.05 level of confidence. It denotes that hand length of handball players remains same among the groups. Since $F$ is not significant Tukey HSD post hoc test was not applied.

Table 1

ANOVA estimate for handball players on hand width

\begin{tabular}{|c|c|c|c|c|c|c|}
\hline Variable & SOV & $\begin{array}{l}\text { Sum of } \\
\text { Squares }\end{array}$ & df & $\begin{array}{l}\text { Mean } \\
\text { Square }\end{array}$ & $\mathbf{F}$ & Sig. \\
\hline \multirow{3}{*}{ Right hand length } & Between Groups & 12.091 & 8 & 1.511 & \multirow{3}{*}{1.61} & \multirow{3}{*}{.126} \\
\hline & Within Groups & 126.386 & 135 & .936 & & \\
\hline & Total & 138.477 & 143 & & & \\
\hline \multirow{3}{*}{ Left hand length } & Between Groups & 9.680 & 8 & 1.210 & \multirow{3}{*}{1.19} & \multirow{3}{*}{.308} \\
\hline & Within Groups & 137.039 & 135 & 1.015 & & \\
\hline & Total & 146.719 & 143 & & & \\
\hline
\end{tabular}

* significant at 0.05 level of confidence

However, it is clear from Table 2 that the obtained $F$ ratio 5.45 and $6.30(p<.000$ and .000$)$ respectively is greater than the table value of 2.51 required at 8 and 144 degree of freedom for 0.05 level of confidence. It denotes that hand width of handball players significantly differ among the groups. 
Table 2

ANOVA estimate for handball players on hand width

\begin{tabular}{|c|c|l|l|l|l|c|}
\hline \multirow{2}{*}{ Variable } & SOV & $\begin{array}{c}\text { Sum of } \\
\text { Squares }\end{array}$ & df & $\begin{array}{c}\text { Mean } \\
\text { Square }\end{array}$ & \multirow{2}{*}{ F } & Sig. \\
\hline \multirow{3}{*}{ Right hand width } & Between Groups & 7.279 & 8 & .910 & \multirow{2}{*}{$5.450 *$} & \multirow{2}{*}{.000} \\
\cline { 2 - 5 } & Within Groups & 22.539 & 135 & .167 & & \\
\cline { 2 - 5 } & Total & 29.818 & 143 & & \multirow{2}{*}{$6.302 *$} & \multirow{2}{*}{.000} \\
\cline { 2 - 5 } Left hand width & Between Groups & 8.556 & 8 & 1.069 & & \\
\cline { 2 - 5 } & Within Groups & 22.910 & 135 & .170 & & \\
\cline { 2 - 5 } & Total & 31.466 & 143 & & & \\
\hline
\end{tabular}

*significant at 0.05 level of confidence

Since $F$ is significant Tukey HSD post hoc test was applied and presented in Table 3. Tukey HSD post hoc test revealed significant differences on right hand width between MU and RU ( $p<.013)$, KU and OU $(p<.026)$, RU and ANU ( $p<$ $.003)$, RU and OU $(p<.000)$, LNUPE and ANU $(p<.020)$, LNUPE and OU $(p<.000)$, OU and RDVU $(p<.030)$. Remaining comparisons showed no significant difference on right hand width.

Similarly on left hand width between SRTU and RU ( $p<.028)$, MU and RU $(p<.047)$, RU and ANU $(p<.000)$, RU and OU $(p<.000)$, LNUPE and ANU $(p<.022)$, LNUPE and OU $(p<.000)$. Remaining comparisons showed no significant difference on left hand width. Graphically hand width of various handball teams is presented in Figure 2.

Figure 2

Graph shows hand width of various handball teams

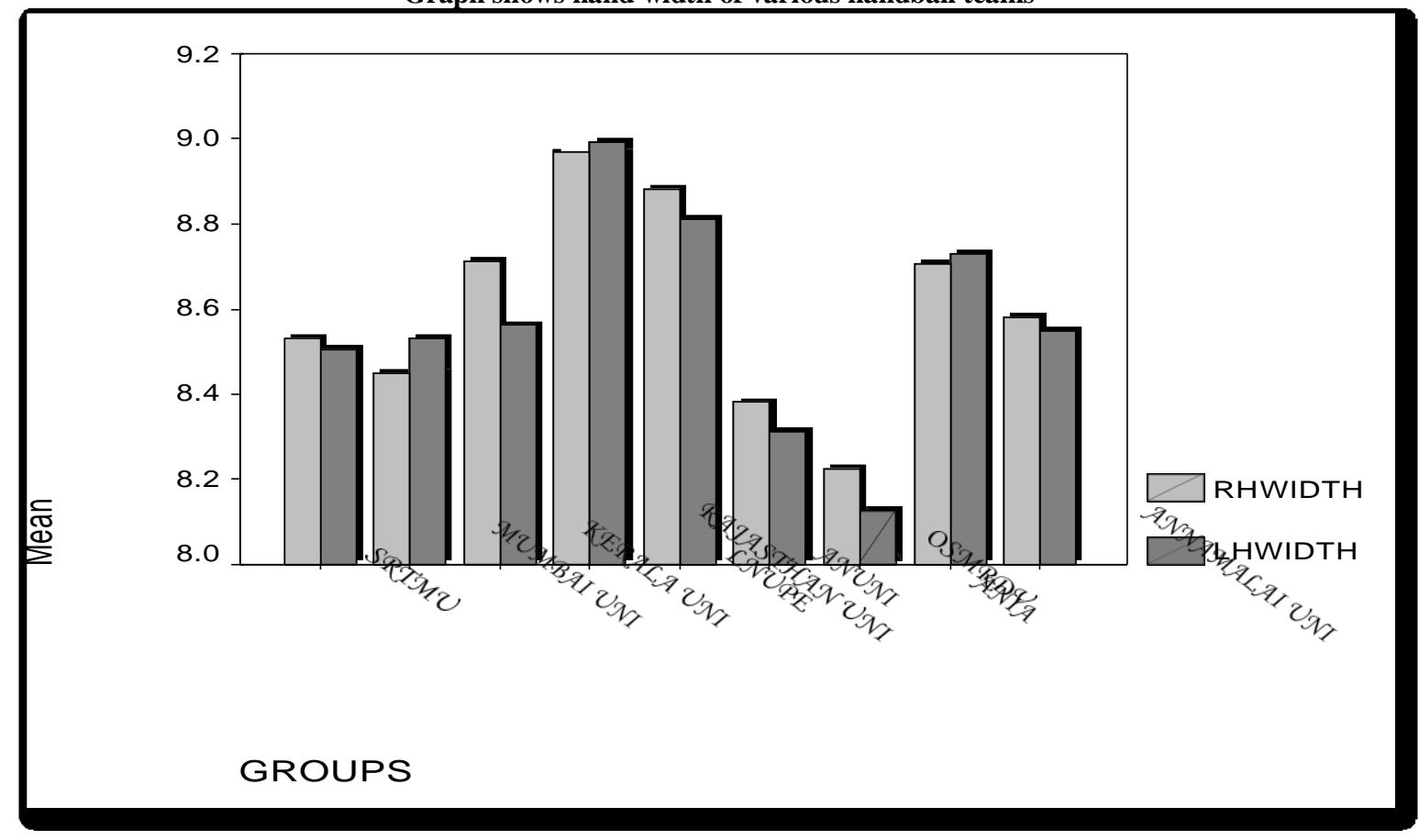


Table 3

Tukey HSD post hoc test on hand width

\begin{tabular}{|c|c|c|c|c|c|c|c|}
\hline \multirow{4}{*}{ Team } & \multirow{4}{*}{$\begin{array}{l}\text { Teams to be } \\
\text { compared }\end{array}$} & \multicolumn{3}{|c|}{ Right hand } & \multicolumn{3}{|c|}{ Left han } \\
\hline & & \multirow{3}{*}{ Sig. } & \multicolumn{2}{|c|}{$\begin{array}{l}\text { 95\% Confidence } \\
\text { Interval }\end{array}$} & \multirow[t]{3}{*}{ Sig. } & \multicolumn{2}{|c|}{$\begin{array}{c}\text { 95\% Confidence } \\
\text { Interval }\end{array}$} \\
\hline & & & Lower & Upper & & Upper & Lower \\
\hline & & & Bound & Bound & & Bound & Bound \\
\hline \multirow[t]{8}{*}{ SRTU } & MU & $=1.00$ & -.3742 & .5367 & $=1.00$ & -.4842 & .4342 \\
\hline & $\mathrm{KU}$ & $=.942$ & -.6367 & .2742 & $=1.00$ & -.5154 & .4029 \\
\hline & RU & $=.070$ & -.8930 & .0180 & $<.028$ & -.9467 & -.0283 \\
\hline & LNUPE & $=.280$ & -.8055 & .1055 & $=.476$ & -.7654 & .1529 \\
\hline & ANU & $=.981$ & -.3055 & .6055 & $=.920$ & -.2654 & .6529 \\
\hline & $\mathrm{OU}$ & $=.464$ & -.1492 & .7617 & $=.189$ & -.0779 & .8404 \\
\hline & RDVU & $=.953$ & -.6305 & .2805 & $=.832$ & -.6842 & .2342 \\
\hline & $\mathrm{AU}$ & $=1.00$ & -.5055 & .4055 & $=1.00$ & -.5029 & .4154 \\
\hline \multirow[t]{7}{*}{ MU } & $\mathrm{KU}$ & $=.671$ & -.7180 & .1930 & $=1.00$ & -.4904 & .4279 \\
\hline & RU & $<.013$ & -.9742 & -.0633 & $<.047$ & -.9217 & -.0033 \\
\hline & LNUPE & $=.079$ & -.8867 & .0242 & $=.594$ & -.7404 & .1779 \\
\hline & ANU & $=1.00$ & -.3867 & .5242 & $=.853$ & -.2404 & .6779 \\
\hline & $\mathrm{OU}$ & $=.826$ & -.2305 & .6805 & $=.128$ & -.0529 & .8654 \\
\hline & RDVU & $=.699$ & -.7117 & .1992 & $=.906$ & -.6592 & .2592 \\
\hline & $\mathrm{AU}$ & $=.992$ & -.5867 & .3242 & $=1.00$ & -.4779 & .4404 \\
\hline \multirow[t]{6}{*}{$\mathrm{KU}$} & RU & $=.699$ & -.7117 & .1992 & $=.084$ & -.8904 & .0279 \\
\hline & LNUPE & $=.962$ & -.6242 & .2867 & $=.735$ & -.7092 & .2092 \\
\hline & ANU & $=.354$ & -.1242 & .7867 & $=.735$ & -.2092 & .7092 \\
\hline & $\mathrm{OU}$ & $<.026$ & .0320 & .9430 & $=.075$ & -.0217 & .8967 \\
\hline & RDVU & $=1.00$ & -.4492 & .4617 & $=.964$ & -.6279 & .2904 \\
\hline & $\mathrm{AU}$ & $=.992$ & -.3242 & .5867 & $=1.00$ & -.4467 & .4717 \\
\hline \multirow[t]{5}{*}{ RU } & LNUPE & $=1.00$ & -.3680 & .5430 & $=.945$ & -.2779 & .6404 \\
\hline & ANU & $<.003$ & .1320 & 1.0430 & $<.000$ & .2221 & 1.1404 \\
\hline & $\mathrm{OU}$ & $<.000$ & .2883 & 1.1992 & $<.000$ & .4096 & 1.3279 \\
\hline & RDVU & $=.671$ & -.1930 & .7180 & $=.681$ & -.1967 & .7217 \\
\hline & $\mathrm{AU}$ & $=.164$ & -.0680 & .8430 & $=.067$ & -.0154 & .9029 \\
\hline \multirow[t]{4}{*}{ LNUPE } & ANU & $<.020$ & .0445 & .9555 & $<.022$ & .0408 & .9592 \\
\hline & $\mathrm{OU}$ & $<.000$ & .2008 & 1.1117 & $<.000$ & .2283 & 1.1467 \\
\hline & RDVU & $=.953$ & -.2805 & .6305 & $=1.00$ & -.3779 & .5404 \\
\hline & $\mathrm{AU}$ & $=.494$ & -.1555 & .7555 & $=.681$ & -.1967 & .7217 \\
\hline \multirow[t]{3}{*}{ ANU } & $\mathrm{OU}$ & $=.976$ & -.2992 & .6117 & $=.933$ & -.2717 & .6467 \\
\hline & RDVU & $=.380$ & -.7805 & .1305 & $=.104$ & -.8779 & .0404 \\
\hline & $\mathrm{AU}$ & $=.902$ & -.6555 & .2555 & $=.786$ & -.6967 & .2217 \\
\hline \multirow[t]{2}{*}{$\mathrm{OU}$} & RDVU & $<.030$ & -.9367 & -.0258 & $=.002$ & -1.0654 & -.1471 \\
\hline & $\mathrm{AU}$ & $=.258$ & -.8117 & .0992 & $=.094$ & -.8842 & .0342 \\
\hline RDVU & AU & $=.994$ & -.3305 & .5805 & $=.945$ & -.2779 & .6404 \\
\hline
\end{tabular}

* The mean difference is significant at the .05 level. 


\section{Discussion}

In our study it was reported that among nine teams they differ significantly in hand width. Earlier studies reported that body height, body mass, palm span and palm length were important for the performance enhancement of athletes and were considered as basic criterion for their selection in various playing positions [2, 3]. Skoufas (2003) reported that wider palm span and longer palm length influenced specific motor abilities such as dribble, passing, catching and ball throwing and contributed to maximizing throwing velocity [4].

The present study was conducted to compare hand length and width among inter university handball players. The major conclusion drawn from this study was that hand width showed significant difference between various handball team. Hand dimensions may influence handgrip strength and the athletes have biomechanical advantages [5]. Hager-ross and Schieber (2000), investigating children at different ages, confirmed that hand length (the distance from wrist joint to the tip of middle finger) is an important variable for handgrip strength [6]. Visnapuu and Jürimäe (2007) indicated that hand perimeters are the most important hand anthropometric variables in relation to handgrip strength. The present study showed that difference in hand width among handball players [5].

\section{Conclusions}

There was no difference in hand length among the selected handball team. On the other hand, Rajasthan University players dominated in right and left hand width. They possess biomechanical advantages than other teams and which influences the grip strength.

\section{References}

[1] A.M. Clerke, J.P. Clerke, R.D. Adams, Effects of hand shape on maximal isometric grip strength and its reliability in teenagers. Journal of Hand Therapy, 18 (2005) 19-29.

[2] V. Srhoj, M. Marinovic, N. Rogulj, Position specific morphological characteristics of top-level male handball players, Collegium Antropologicum, 26 (2002) 219-227.

[3] F. Taborsky, The body height and top team handball players, EHF web Periodical (2007) Vienna / Austria.

[4] D. Skoufas, C. Kotzamanidis, K. Hatzikotoylas, G. Bebetsos, D. Patikas, The relationship between the anthropometric variables and throwing performance in handball, Journal of Human Movement Science, 45 (2003) 469-484.

[5] M. Visnapuu, T. Jürimäe, Handgrip strength and hand dimensions in young handball and basketball players. Journal of Strength and Conditioning Research, 21 (2007) 923-929.

[6] C. Hager-Ross, M.H. Schieber, Quantifying the independence of human finger movements: Comparisons of digits, hands and movement frequencies, Journal of Neuroscience, 20 (2000) 8542-8550. 